\title{
Protein stabilization by RSUME accounts for PTTG pituitary tumor abundance and oncogenicity
}

\author{
M Fuertes', M Sapochnik1, L Tedesco', S Senin', A Attorresi', P Ajler², G Carrizo², A Cervio³, G Sevlever³, \\ J J Bonfiglio', G K Stalla4 and E Arzt1,5
}

\author{
1'Instituto de Investigación en Biomedicina de Buenos Aires (IBioBA) - CONICET - Partner Institute of the Max Planck Society, Buenos Aires, Argentina \\ 2Servicio de Neurocirugía, Hospital Italiano, Buenos Aires, Argentina \\ ${ }^{3}$ Departamento de Neurocirugía, Fundación Para la Lucha Contra las Enfermedades Neurológicas de la Infancia (FLENI), Buenos Aires, Argentina \\ ${ }^{4}$ Department of Clinical Research, Max Planck Institute of Psychiatry, Munich, Germany \\ ${ }^{5}$ Departamento de Fisiología y Biología Molecular y Celular, Facultad de Ciencias Exactas y Naturales, Universidad de Buenos Aires, Buenos \\ Aires, Argentina
}

Correspondence should be addressed to E Arzt: earzt@ibioba-mpsp-conicet.gov.ar

\begin{abstract}
Increased levels of the proto-oncogene pituitary tumor-transforming gene 1 (PTTG) have been repeatedly reported in several human solid tumors, especially in endocrinerelated tumors such as pituitary adenomas. Securin PTTG has a critical role in pituitary tumorigenesis. However, the cause of upregulation has not been found yet, despite analyses made at the gene, promoter and mRNA level that show that no mutations, epigenetic modifications or other mechanisms that deregulate its expression may explain its overexpression and action as an oncogene. We describe that high PTTG protein levels are induced by the RWD-containing sumoylation enhancer (RWDD3 or RSUME), a protein originally identified in the same pituitary tumor cell line in which PTTG was also cloned. We demonstrate that PTTG and RSUME have a positive expression correlation in human pituitary adenomas. RSUME increases PTTG protein in pituitary tumor cell lines, prolongs the half-life of PTTG protein and regulates the PTTG induction by estradiol. As a consequence, RSUME enhances PTTG transcription factor and securin activities. PTTG hyperactivity on the cell cycle resulted in recurrent and unequal divisions without cytokinesis, and the consequential appearance of aneuploidies and multinucleated cells in the tumor. RSUME knockdown diminishes securin PTTG and reduces its tumorigenic potential in a xenograft mouse model. Taken together, our findings show that PTTG high protein steady state levels account for PTTG tumor abundance and demonstrate a critical role of RSUME in this process in pituitary tumor cells.
\end{abstract}

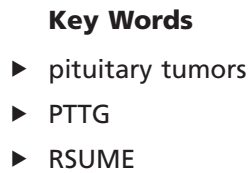

Endocrine-Related Cancer (2018) 25, 665-676

\section{Introduction}

Considerable progress has been achieved in identifying mechanisms/factors that are involved in pituitary tumor initiation and progression (Dworakowska \& Grossman 2012, Perez-Castro et al. 2012, Gatto et al. 2013, Farrell
2014). Despite their high prevalence in the general population (Beckers 2010, Fernandez et al. 2010), these tumors are invariably benign and exhibit features of differentiated pituitary cell function as well as premature 
proliferative arrest (Melmed 2011, Sapochnik et al. 2017). Most pituitary adenomas develop sporadically, and only a small proportion of pituitary adenomas have a hereditary background. Disturbed cell-cycle regulator expression and action resulting in aberrant cell-cycle control is often observed in pituitary tumors (Clayton \& Farrell 2004, Quereda \& Malumbres 2009, Drouin et al. 2010).

Originally isolated from rat pituitary tumor cells (Pei \& Melmed 1997), PTTG was subsequently identified as a member of the securin family of proteins (Zou et al. 1999). PTTG, a multifunctional protein, is a transcription factor and a well-established cell-cycle regulator (RamosMorales et al. 2000, Tong et al. 2007, Tong et al. 2008), with functions in cell replication (Zou et al. 1999), DNA damage/repair (Romero et al. 2001), organ development, metabolism, cell transformation (Wang et al. 2001, Cancer Genome Research Network 2003) and cell senescence (Chesnokova et al. 2007, 2008). PTTG has been identified in human tissues with a low expression in normal cells, but overexpression in a wide variety of human solid tumors, especially in endocrine-related tumors such as thyroid, pituitary, breast, ovarian and uterine carcinomas, and also non-endocrine tumors such as pulmonary, gastrointestinal and renal cell carcinomas, malignancies of the CNS, melanoma and blastic leukemia (Dominguez et al. 1998, Heaney et al. 2000, Solbach et al. 2004, Ogbagabriel et al. 2005, Ito et al. 2008, Tong \& Eigler 2009). Its expression positively correlates with tumor invasiveness and recurrence (Zhang et al. 1999a, Boelaert et al. 2003, Amousha et al. 2015).

The product of the RWDD3 gene, RSUME, was identified by differential expression also in rat pituitary tumor cells (Carbia-Nagashima et al. 2007). RSUME increases protein sumoylation (Carbia-Nagashima et al. 2007), a dynamic post-translational modification that regulates, like protein ubiquitination (Ciechanover 1994), many key cellular processes (Hay 2005, Geiss-Friedlander $\&$ Melchior 2007). RSUME is expressed in several normal tissues and is induced by heat shock (Druker et al. 2013) and hypoxia (Carbia-Nagashima et al. 2007, Gerez et al. 2013, 2015, He et al. 2017). It is differentially expressed in cells with high tumoral and angiogenic potential (CarbiaNagashima et al. 2007, Shan et al. 2012, Gerez et al. 2013, 2015, He et al. 2017) and has been associated with the gene expression signature of breast cancer patients (Huang et al. 2013, Schneider et al. 2015) and decreased survival in a group of renal cell carcinoma patients (Cancer Genome Research Network 2003, Gao et al. 2013).

No mutations, epigenetic modifications or other mechanisms that explain high PTTG expression and action as oncogene have been described so far. The aim of the study was to identify causes that modify PTTG abundance. We demonstrate in pituitary cells and xenograft transplanted animals that RSUME increases PTTG protein stability, altering its transcription factor and securin activity, resulting in recurrent cell division without cytokinesis and tumor development. Together, these results reveal the regulation of PTTG abundance at the protein level and the interplay of RSUME and PTTG in tumor development of pituitary gland.

\section{Materials and methods}

Unless otherwise stated, reagents were obtained from Life Technologies/Thermo Fisher Scientific or Sigma-Aldrich/ Merck.

\section{Plasmids and cloning}

The following plasmids were kindly provided by: pCEFL, O Coso; Gam1 wt and mut, S Chiocca; c-MYC-LUC, K Mitsuyasu; cycD3-LUC, K Ohtani; CMV- $\beta g a l$, D Spengler. V5-RSUME and RSUME-Luc were obtained as described (Carbia-Nagashima et al. 2007). HA-PTTG was constructed by cloning hPTTG1 cDNA into the Bgl II-Not I sites of the pCEFL expression vector. The nucleotide sequences of all constructs were confirmed by DNA sequencing.

\section{Cell culture and stimulation}

Cell lines AtT-20 (mouse corticotroph cell line), GH3 (rat lactosomatotroph cell line), GH4 (rat lactosomatotroph cell line) and COS-7 (African green monkey kidney fibroblast-like cell line) were acquired from ATCC, either directly or by colleagues. Cells were cultured in Dulbecco's modified Eagle's medium (pH 7.3) supplemented with 10\% fetal bovine serum, $2.2 \mathrm{~g} / \mathrm{L} \mathrm{NaHCO}_{3}, 10 \mathrm{mmol} / \mathrm{L}$ HEPES, $2 \mathrm{mmol} / \mathrm{L}$ glutamine and $10^{5} \mathrm{U} / \mathrm{L}$ penicillin/streptomycin, under a $5 \% \mathrm{CO}_{2}$ atmosphere at $37^{\circ} \mathrm{C}$. AtT- 20 or GH4 clones, generated as indicated in the following section, were cultured under the same conditions but adding Geneticin (G418) to the medium. For cycloheximide (CHX) stimuli, cells were cultured in medium with $100 \mu \mathrm{g} / \mathrm{mL} \mathrm{CHX}$ for the indicated times. For estradiol (E2) stimuli, cells were cultured in DMEM without phenol red for a week at least. Cells were treated with $100 \mathrm{nM}$ E2 for the indicated times.

\section{Stable clones generation}

AtT-20 or GH4 stable clones were obtained as described (Paez-Pereda et al. 2003). Cells were transfected 
with each shRNA plasmids directed against RSUME (5'-GGAGAAGTGGGCTTCAGATTT-3') or Scramble (5'-GGAATCTCATTCGATGCATAC-3') from SABiosciences (Hilden, Germany). Clones were selected as a pool with $600 \mu \mathrm{g} / \mathrm{mL}$ Geneticin and maintained with $300 \mu \mathrm{g} / \mathrm{mL}$ Geneticin. PTTG and RSUME expression levels were checked by WB.

\section{Primary cell cultures}

Mouse embryonic fibroblast (MEF) primary cell cultures were prepared from CF-1 embryonic day 13.5 (E13.5) embryos. The red organs of embryos were removed, single torsos were minced and cells dispersed by rotation for $30 \mathrm{~min}$ in $0.1 \%$ trypsin-EDTA solution at $37^{\circ} \mathrm{C}$. Cells were washed once in PBS, taken up in DMEM containing 20\% FBS, and plating for culture. MEF cells were maintained in DMEM with $20 \%$ FBS. Cells at passages 2 or 3 were plated at $100-\mathrm{mm}$ dish, and transfected.

\section{Testis primary cell cultures}

Mouse fetal testis primary cell cultures were prepared from CF-1 embryonic day 18.5 (E18.5) embryos. The testes of male embryos were minced, and cells dispersed by rotation for $30 \mathrm{~min}$ in $0.05 \%$ collagenase at $37^{\circ} \mathrm{C}$. Cells were washed once in HBSS (Gibco), taken up in DMEM containing 20\% FBS, and plating for culture. Cells were plated at 100-mm dish, and transfected.

\section{Tumor samples}

Human pituitary adenoma tissues were obtained from the Neurosurgery Service, Hospital Italiano, Argentina and Neurosurgery Department, FLENI, Argentina. This study complies with the June 1964 Declaration of Helsinki and has been approved by the hospital ethics committee; informed written consent was received from each patient whose tumor tissue was used in the study. A portion of the tumor tissue, after transsphenoidal surgery, was received in sterile medium and treated with standard cracking buffer. A total of 23 pituitary adenomas were diagnosed according to clinical, biochemical, radiological and surgical findings as well as by routine immunohistochemistry and were classified as somatotrophinomas $(n=4)$, corticotrophinomas $(n=6)$, prolactinomas $(n=3)$, plurihormonal adenoma $(n=1)$, nonfunctioning adenomas $(n=6)$ and gonadotrophinomas $(n=3)$, with the last used for aneuploidy studies. For these aneuploidy analysis, tumor cell cultures were performed as described (Paez-Pereda et al. 2003) and incubated in $5 \mu \mathrm{g} / \mathrm{mL}$ Colcemid for $24 \mathrm{~h}$. Further, chromosome analysis was made.

\section{Mouse tissue samples}

Mouse pituitary, kidney and testis were dissected from CD-1 mice, put in a tube with standard cracking buffer for proteins, homogenized by ULTRA-TURRAX dispersers PRO sc-250 (IKA) and sonicated for 10 s to $20 \%$ potency. For pituitary tissue, we polled 3 animals.

\section{Transfections}

Cell transfection with siRNA against RSUME or scramble (Carbia-Nagashima et al. 2007) was performed using Lipofectamine 2000; COS-7 and GH4 cells were transfected using Lipofectamine 2000; AtT-20 and GH3 were transfected using Lipofectamine; MEFs cells and mouse fetal testis primary cell cultures were transfected using calcium phosphate method. Transfections with Lipofectamine reagent were performed following the manufacturer's instructions.

\section{Western blot}

$48 \mathrm{~h}$ post-transfection, cell lysates were prepared in standard cracking buffer and boiled for $5 \mathrm{~min}$ at $95^{\circ} \mathrm{C}$. Cell extracts were subjected to SDS-polyacrylamide gel electrophoresis (SDS-PAGE) as previously described (Paez-Pereda et al. 2003). Proteins were blotted onto nitrocellulose membranes using standard procedures, and incubated with antibodies to PTTG (34-1500, 1:500) from Zymed; V5 (ab9116, 1:3000), RWDD3 (ab128285, 1:1000) and GAPDH (ab8245, 1:10,000) from Abcam; $\beta$-actin (C4 sc-47778, 1:3000) from Santa Cruz Biotechnology.

\section{Immunoprecipitation}

$48 \mathrm{~h}$ post transfection, cells were washed with PBS, lysed on ice with modified RIPA buffer and immunoprecipitated with anti-HA (Covance) antibody as described (PaezPereda et al. 2003). Mock corresponds to the condition with all the plasmids transfected and immunoprecipitated with unspecific IgG of the same isotype of the antibody used to precipitate. 


\section{Luciferase assay}

Cells were harvested and luciferase activity was measured as previously described (Carbia-Nagashima et al. 2007).

\section{Chromosome analysis}

$24 \mathrm{~h}$ post transfection, MEF cells were treated with $5 \mu \mathrm{g} / \mathrm{mL}$ Colcemid (to obtain mitotic cells, Metaphase) or serum starvated (to obtain cells in interphase) for $24 \mathrm{~h}$, collected, hypotonized with $0.075 \mathrm{M} \mathrm{KCl}$ and fixed with cold methanol/acetic 3:1. Fixed cells were processed by standard cytogenetic procedures with 5\% Giemsa or $1 \mu \mathrm{g} / \mathrm{mL}$ DAPI staining. Chromosome number and gross rearrangements were determined in at least 50 metaphase or interphase cells.

\section{Immunofluorescence}

For multinucleated cell experiments, MEF cells were analyzed by immunofluorescence using antiVimentin VI-10 antibody (Abcam) with Alexa Fluor 647-conjugated secondary antibody; nuclei were stained with Hoescht. For mitotic bridge, MEF cells were analyzed using anti- $\alpha$-Tubulin TU-01 antibody (Abcam) with Alexa Fluor 647-conjugated secondary antibody; nuclei were stained with DAPI. Images were captured by an inverted AxioObserver Z1 LED Colibrí microscope (Carl Zeiss).

\section{Proliferation assay}

$5 \times 10^{3}$ cells were plated and $72 \mathrm{~h}$ later, a WST- 1 assay (Roche) was used to measure viability and proliferation following the manufacturer's instructions. The reaction products were measured in an ELISA plate reader at $450 \mathrm{~nm}$, as previously described (Paez-Pereda et al. 2003).

\section{Xenograft assay in nude mice}

AtT-20 or GH4 derived clones were harvest by trypsinization, washed twice with PBS, resuspended in DMEM and injected subcutaneously, as described (PaezPereda et al. 2003), into the flanks of 6- to 8-week-old male nude mice (strain N:NIH (S)-FoxnInu), obtained from Fundación Facultad de Ciencias Veterinarias, National University of La Plata, Argentina. Twelve mice were injected with $3 \times 10^{6}$ cells of AtT-20 ( 6 for shRSUME and 6 for shSCRAMBLE) or $2 \times 10^{6}$ cells of GH4 ( 6 for shRSUME and 6 for shSCRAMBLE) in two independent experiments



B


Figure 1

RSUME and PTTG are co-expressed in human pituitary tumors. (A) Representative Western blot (WB) analysis in samples of each type of human pituitary tumors. GAPDH was used as loading control. Normal mouse tissues as negative or positive controls of PTTG or RSUME expression are shown in the bottom panel. (B) Graphs show ratio of intensity between PTTG or RSUME and GAPDH for each group of tumors (1 mixed adenoma, 4 somatotrophinomas, 6 corticotrophinomas, 6 non-functioning adenomas and 3 prolactinomas). Graph of correlation analysis between PTTG and RSUME expression; Pearson correlation with Pearson coefficient $=0.8388, R^{2}=0.7036, P<0.0001$. 
of six animals for each cell clone. Animals were examined for tumor formation every 3 days and tumor growth was determined as described (Paez-Pereda et al. 2003). All experimental protocols were approved by the Ethical Committee on Animal Care and Use (CICUAL), University of Buenos Aires, Argentina.

\section{Statistical analysis}

Statistics were performed by analysis of variance (ANOVA) in combination with the Scheffé's test. Data are shown as mean \pm s.e.m. Correlations between variables were evaluated by Pearson's correlation. Statistical significance was accepted at $P<0.05$.

\section{Results}

We first examined a potential relationship between PTTG and RSUME, both originally cloned from the same cell type (Pei \& Melmed 1997, Carbia-Nagashima et al. 2007). We noticed that RSUME and PTTG are co-expressed in explants of different types of human pituitary tumors and the expression correlates significantly (Fig. 1A and B). Normal mouse pituitary and kidney tissues, negative controls not expressing PTTG (Pei \& Melmed 1997,
Zhang et al. 1999b) but RSUME (Carbia-Nagashima et al. 2007), are shown (Fig. 1A).

RSUME overexpression increases PTTG protein steady state levels, both in transfected COS-7 cells that do not express PTTG and in pituitary tumor cell line GH4 that do express PTTG endogenously (Fig. 2A). Also, in primary cultures of mouse fetal testis, a known tissue that expresses high levels of PTTG (Pei 1999), RSUME increases PTTG protein levels (Fig. 2B). Consequently, RSUME knockdown with a specific small interfering RNA (siRNA) has the opposite effect on PTTG protein levels (Fig. 2C). In cells in which PTTG protein is not present, such as non-transfected COS-7 cells in Fig. 2A and normal mouse pituitary and kidney tissues in Fig. 1A, RSUME has no action on PTTG. To ascertain that protein stability accounts for the increase in PTTG levels, transfected COS-7 cells were treated for different times with cycloheximide; after treatment, PTTG protein expression levels declined, and RSUME slowed the decay and increased the half-life of PTTG in 50\% (from 2 to $4 \mathrm{~h}$ ) (Fig. 2D). In accordance with PTTG mRNA (Heaney et al. 1999), PTTG protein levels increased after the addition of 100-nM estradiol (E2) and downregulation of RSUME resulted in the blockage of this time-dependent induction by E2 (Fig. 2E). As RSUME is a sumoylation enhancer, we analyzed the PTTG
A
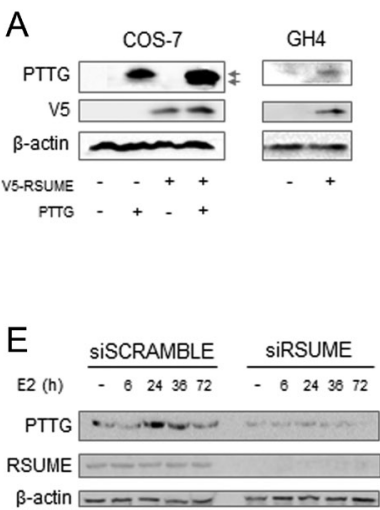

B

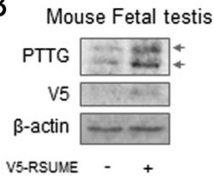

C



$\mathrm{F}$

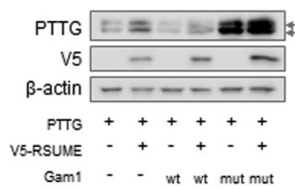

G

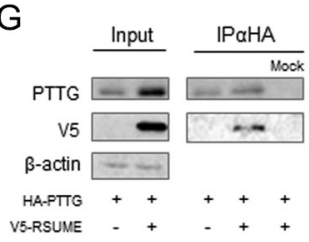

$\mathrm{D}$

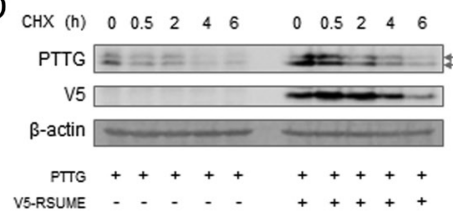

$\mathrm{H}$



\section{Figure 2}

RSUME causes PTTG protein stabilization. (A) Representative WB analysis of COS-7 or GH4 cells transfected with a RSUME-expressing or empty vector $(n=3)$. COS-7 cells were also transfected with a PTTG-expressing plasmid. (B) Representative WB analysis in primary cultures of mouse fetal testis at embryonic day 18.5 transfected with a RSUME-expressing or empty vector $(n=2)$. (C) Representative WB analysis of COS-7 or GH4 cells transfected with a small interference RNA (siRNA) against RSUME or Scramble $(n=3)$. COS-7 cells were also transfected with PTTG and/or RSUME-expressing plasmids. (D) Representative WB analysis of COS-7 cells transfected with PTTG- and/or RSUME-expressing vectors and treated with cycloheximide $(\mathrm{CHX})(100 \mu \mathrm{g} / \mathrm{mL}) \mathrm{for}$ the indicated times $(n=4)$. (E) Representative WB analysis of GH3 cells transfected with an siRNA against RSUME or Scramble, and stimulated with estradiol (E2) $(100 \mathrm{nM})$ for the indicated times $(n=3)$. (F) Representative WB analysis of COS-7 cells transfected with PTTG, RSUME and Gam1 wt or mutant-expressing vectors $(n=4)$. (G) Representative WB analysis for PTTG and RSUME after immunoprecipitation (IP) of HA-PTTG, with anti-HA, from COS-7 cells transfected with PTTG and/or RSUME $(n=3)$. (H) Luciferase activity of COS-7 cells transfected with $0.2-0.6 \mu g$ PTTG-expressing vector and RSUME reporter vector $(n=3)$. First column are cells transfected with the corresponding empty vectors. Error bars represent mean \pm s.E.M. ${ }^{*} P<0.05$ compared with cells with empty vector (ANOVA with Scheffé's test). In WB, $\beta$-actin was used as loading control. Arrows, phosphorylated (upper) and unphosphorylated (lower) forms of PTTG. Note that in some cells, the increase in protein stability was observed also in the phosphorylated (active) PTTG, probably due to the expression level attained, which is not observed at endogenous levels in GH4 cells. 
stability in the presence of Gam1 (a viral enzyme that inhibits sumoylation (Boggio et al. 2004)) and we found diminished protein levels of PTTG, even in the presence of RSUME (Fig. 2F). With a Gam1 mutant that lacks activity on the SUMO-pathway (Boggio et al. 2004), this effect was reversed (Fig. 2F). Analyzing in silico the sequence of PTTG looking for potential sumoylation sites with the software SUMOplot and SUMOsp, we obtained that human PTTG1 protein has many potentially sumoylable lysines, but both software predicted that the lysine with greater likelihood of sumoylation is K168, which is part of a nonconsensus sumoylation site (sequence -VKMP-). The SUMOsp software also predicts that residues 4-8 constitute a SUMO interaction motif.

We observed by co-inmunoprecipitation that PTTG and RSUME proteins interact (Fig. 2G), which provides the structural basis for the action of RSUME on PTTG stability. Interestingly, PTTG increases the induction of RSUME (Fig. 2H).

To understand the functional consequences of PTTG stability, we initially studied PTTG transcription factor activity. In correspondence to increased levels of endogenous PTTG protein, an increment on promoter activation of c-MYC (Fig. 3A) and cyclin D3 (Fig. 3B) is observed in response to increasing amounts of RSUME. At high RSUME concentrations, without exogenous PTTG, we observed an increase of c-MYC activation concomitant with an endogenous PTTG protein increase. Downregulation of RSUME resulted in a significant decrease in the transcriptional activity of PTTG on both promoters (Fig. 3C).
Second, we investigated the action of RSUME on the function of PTTG as securin. For this, we used primary cultures of MEF given the impossibility to study aneuploidy in cell lines. MEF cells transfected with empty vector showed a normal appearance in interphase, count of $2 n=40$ chromosomes in metaphase (Fig. 4A, Vectors), and very few binucleated cells (Fig. 4B, Vectors), while MEF cells co-expressing PTTG and RSUME, in concurrence with the observed PTTG abundance (Fig. 4C), resulted in increased genomic instability. We observed an increase in the frequency of aneuploid cells (Fig. 4A), in the detection of chromosomal abnormalities (micronuclei, chromosome fusions, mitotic bridge) (Fig. 4A), and in the frequency of occurrence of binucleated cells (Fig. 4B). Notably, some cells from human pituitary tumor samples had aneuploidies (Fig. 4D).

In a corticotroph cell line AtT-20, RSUME overexpression increases PTTG protein steady state levels (Fig. 5A). We established stable shRSUME clones of the pituitary cell lines AtT-20 and GH4 and confirmed the silencing of RSUME (shRSUME) and consequent decreased levels of PTTG protein, compared to shSCRAMBLE clones (Fig. 5B). shRSUME clones presented a significant inhibition of cell proliferation with respect to the parental cells and shSCRAMBLE clones (Fig. 5C). Nude mice injected with AtT-20 shRSUME stable clones did not develop tumors compared to mice injected with AtT-20 shSCRAMBLE clones (Fig. 5D). Meanwhile, the GH4 shRSUME clones developed slower growing tumors than GH4 shSCRAMBLE clones (Fig. 5D). In AtT-20 and GH4 shRSUME clones in which PTTG was re-expressed,


Figure 3

RSUME increases PTTG transcription factor activity. (A and B) Luciferase activity of GH4 cells transfected with $0.1-0.5 \mu g$ PTTG and/or $0.1-0.9 \mu g$ RSUME-expressing vectors, for c-MYC (A) or cycD3 (B) reporter vector $(n=3)$. WB of PTTG expression is shown, in which arrows indicate phosphorylated (upper) and unphosphorylated (lower) forms of PTTG. Error bars represent mean \pm S.E.M. (C) Luciferase activity of GH4 cells transfected with siRNA against RSUME or Scramble, and/or PTTG-expressing vector $(n=3)$. First column are cells transfected with the corresponding empty vectors. Error bars represent mean \pm S.E.M. ${ }^{*} P<0.05$ compared with cells with the corresponding empty vector (ANOVA with Scheffé's test). 

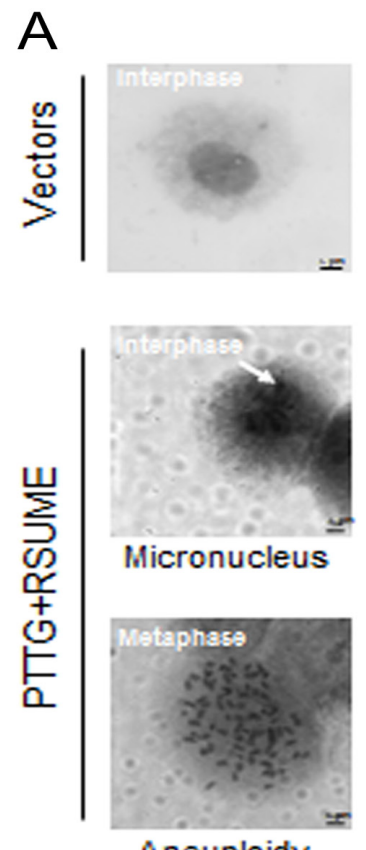

Aneuploidy

B
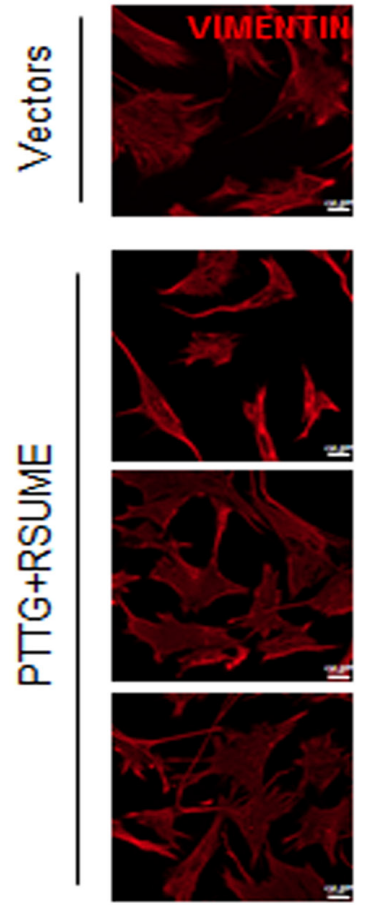
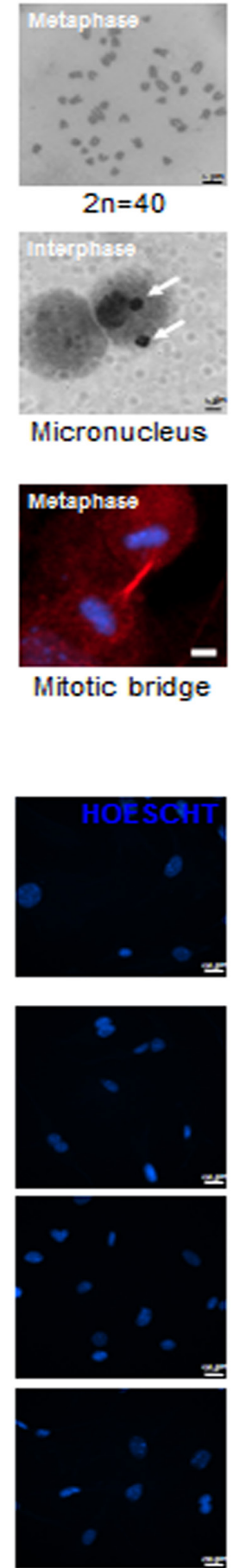

$2 n=40$
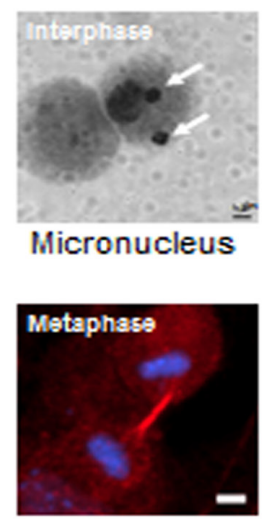

Mitotic bridge

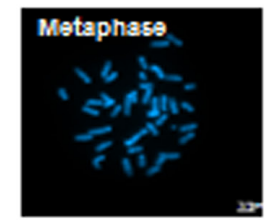

$2 n=40$

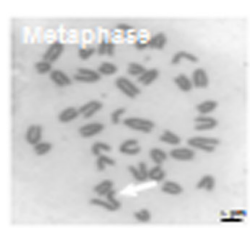

Chromosome fusion



Aneuploidy
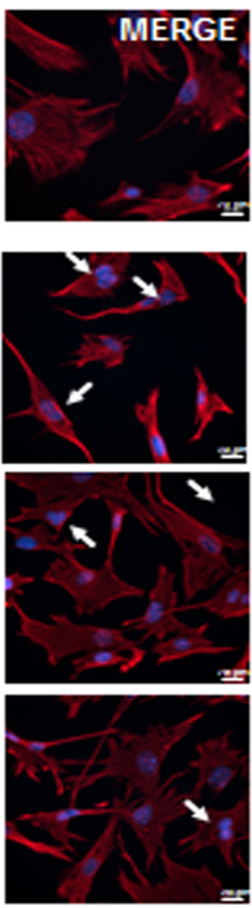

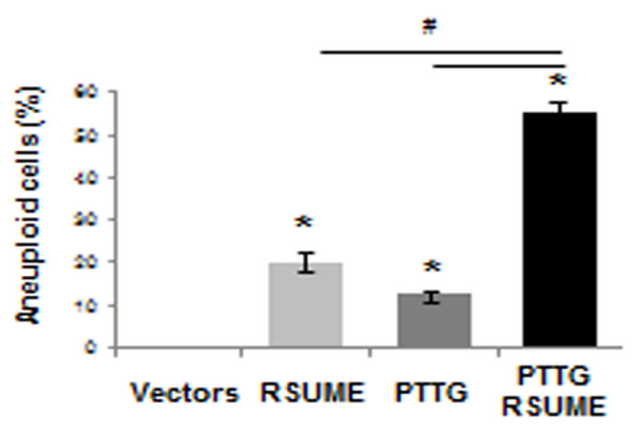

C
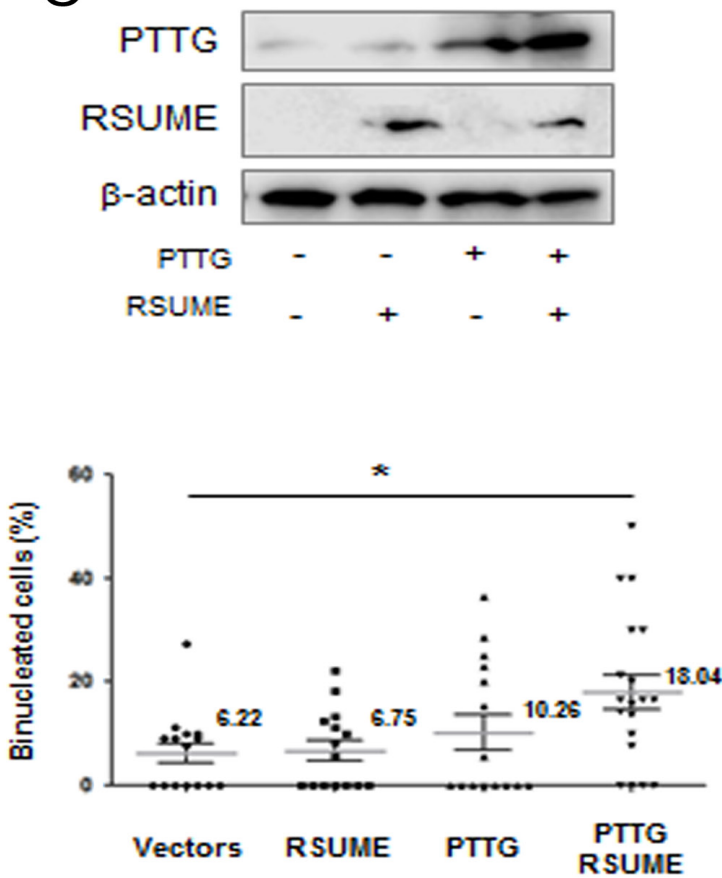

D

Pituitary tumors
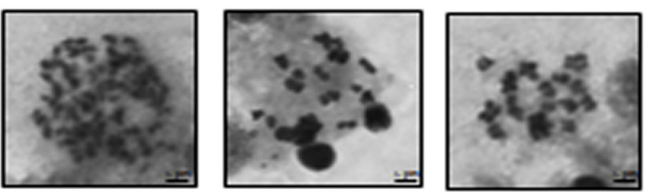

Figure 4

RSUME regulates PTTG securin function. (A) Representative cytochemistry images showing staining of Giemsa (5\%) or DAPI (1 $\mu \mathrm{g} / \mathrm{mL})$ in MEF cells transfected with PTTG- and RSUME-expressing plasmids or empty vectors, and arrested on interphase or metaphase. Representative image of mitotic bridge was obtained by immunohistochemistry of $\alpha$-tubulin (red) and DAPI $(1 \mu \mathrm{g} / \mathrm{mL})$ (blue). Scale bar, $5 \mu \mathrm{m}$. Graph shows quantification of percentage of aneuploidy cells $(n=3)$. Arrow, chromosome abnormalities (B) Representative immunofluorescence images showing staining of Vimentin (red) and Hoescht (blue) in MEF cells transfected with PTTG- and RSUME-expressing plasmids or empty vectors $(n=3)$. Scale bar, $20 \mu \mathrm{m}$. Arrow, binucleated cells. Graph shows quantification of percentage of binucleated cells per field. For all the experiments: ${ }^{P}<0.05$ compared with cells with the corresponding empty vector (ANOVA with Scheffé's test). (C) Representative WB analysis of MEF cells transfected with PTTG- and RSUME-expressing plasmids or empty vectors $(n=2)$. $\beta$-actin was used as loading control. (D) Representative chromosome images showing staining of $5 \%$ Giemsa in human pituitary tumor samples (3 gonadotrophinomas). Scale bar, $5 \mu \mathrm{m}$. 
A

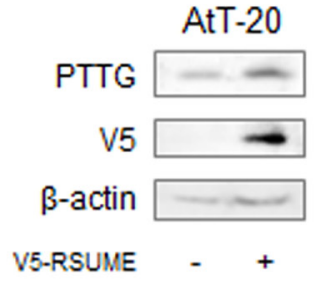

C
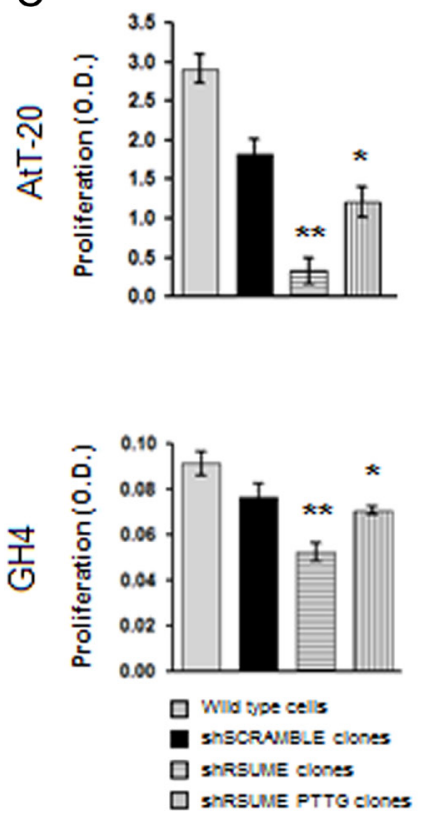

B

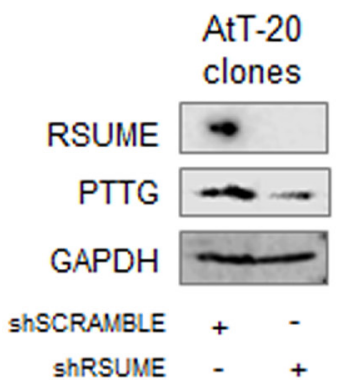

D

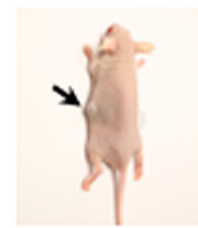

AtT-20 ShSCRAMBLE ShRSUME

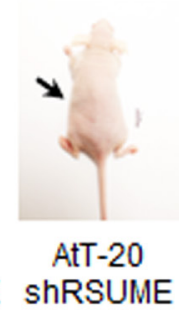

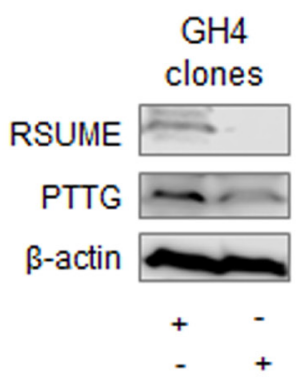

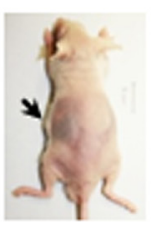

$\mathrm{GH} 4$ ShSCRAMBLE ShRSUME
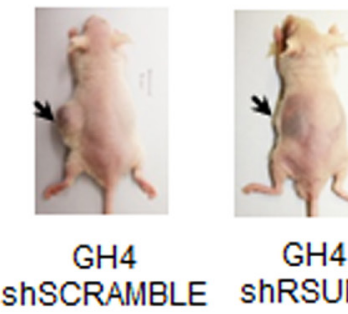

AtT-20

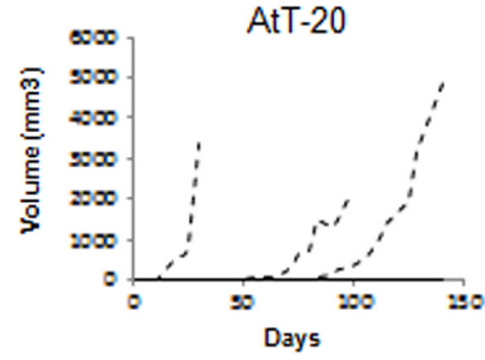

$\mathrm{GH} 4$

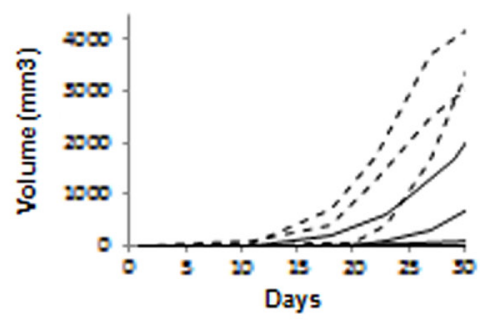

-.. snSCRAMBLE Done

- shrsume clones

Figure $\mathbf{5}$

RSUME knockdown abolishes tumorigenic and proliferative capacity of PTTG. (A) Representative Western blot (WB) analysis of AtT-20 cells transfected with a RSUME-expressing or empty vector $(n=3)$. (B) Representative WB analysis of AtT-20 or GH4 stable clones ( $n=3$ ). (C) Wst- 1 cell proliferation assay of AtT-20 or GH4 stable clones. Error bars represent mean \pm s.E.M. $(n=3)$. shRSUME PTTG, clones transfected with PTTG-expressing vector. **P<0.05 compared with wild type or shSCRAMBLE cells; ${ }^{*} P<0.05$ compared with shRSUME cells (ANOVA with Scheffé's test). (D) Xenograft tumor assay in male athymic nude mice injected subcutaneously with AtT-20 or GH4 stable clones. Representative images were taken at 60 days (AtT-20) or 20 days (GH4) after injection. Graph shows tumoral volume vs days after injection. One of two independent experiments with 3 mice in each group in each experiment with similar results is shown $(n=12)$. shSCRAMBLE clones, dotted line; shRSUME clones, full line. In WB, GAPDH or $\beta$-actin was used as loading control. A full color version of this figure is available at https://doi.org/10.1530/ERC-18-0028.

the decrease in proliferation was reversed (Fig. 5C, bar 'shRSUME PTTG').

\section{Discussion}

The causes of PTTG upregulation in pituitary adenomas remain still an open question. In this study, we demonstrate that PTTG and RSUME are both overexpressed in human pituitary tumors with expression levels that correlate positively. In accordance, RSUME increases PTTG protein in pituitary tumor cell lines, improves the half-life of PTTG protein and regulates the PTTG induction by estradiol. Consequently, RSUME enhances PTTG transcription factor and securin activities. RSUME knockdown reverts its actions on PTTG abundance and transcriptional activity and reduces PTTG tumorigenic potential in a xenograft animal model.

In summary, we found that PTTG overexpression in tumoral cells is explained by its protein stabilization, is regulated by RSUME and accounts for PTTG tumor abundance and pathogenic action. There is no evidence so far that this mechanism operates in normal cells. This finding puts in a central role the protein stabilization- 
overexpression of proto-oncogenes as major regulators of cellular dysfunction.

Increased stability of PTTG induced by RSUME may affect the activation of cell cycle by at least two ways: induction of entry to cycle by c-MYC and progression through the G1/S by cyclin D3, but also exacerbation of the activity of PTTG as securin, resulting in recurrent and unequal divisions (without proper separation of sister chromatids) without cytokinesis.

PTTG overexpression triggers a state of unscheduled proliferation, favoring the appearance of chromosomal abnormalities and the consequent tumor development. In endocrine tumors, where PTTG is abundant, it is not uncommon to find pleomorphic nuclei isolated without definite prognostic implication and that are probably aneuploid (Mastronardi et al. 2001, Yu et al. 2003, Uccella et al. 2005). The design of antitumor drugs that target PTTG abundance would be an interesting therapeutic tool for many tumors which manifest PTTG upregulation. Particularly, C-terminal proline-proline-serine-proline motif auto-regulating human PTTG1, although probably not involving RSUME as it is transcriptional, is an interesting target that could be effective to reduce the function and growth of pituitary tumor cells (Horwitz et al. 2003).

RSUME was identified as a sumoylation regulator that enhances overall SUMO conjugation to target proteins (Carbia-Nagashima et al. 2007). Here, we observed declined PTTG protein levels when the sumoylation pathway was inhibited by the viral protein Gam1 (Boggio et al. 2004), and a consequent reversion of this effect when an inactive mutant was used, which suggests that SUMO signaling is involved in PTTG stabilization by RSUME. For many proteins, sumoylation appears to protect target proteins from proteasomal degradation in addition to enhancing protein stability, changing subcellular localization or distribution, and/or modifying molecular interactions of target substrates (Hay 2005).

This work is the first report of interaction of two key pituitary factors, PTTG and RSUME, both originally identified following a screen of somatolactotroph pituitary tumor cell line. In the case of RSUME, the somatolactotroph cells overexpressed gp130 (Castro et al. 2003), a transmembrane glycoprotein that belongs to the family of interleukin-6 cytokine receptors (Arzt et al. 1999) that signal through JAKs and STATs proteins. Fowkes and Vlotides described that RSUME has at least two putative JAK-STAT sensitive tyrosine phosphorylation sites (Fowkes \& Vlotides 2012). It was described that STAT3 induces PTTG expression to facilitate tumor growth and metastasis in colorectal cancer (Zhou et al. 2014) and that PTTG expression is regulated by IL-6 via activated STAT3 in prostate cancer (Huang et al. 2018). These experimental evidence increases the interest to further study the link between these three proteins, PTTG, RSUME and STAT3. Activation of these pathways involving IL-6/gp130/JAK/STAT3, either through elevated cytokine signaling during inflammation or during stress conditions, could lead to increased RSUME expression or activity, resulting in enhanced PTTG stability and transcriptional activation. Interestingly, in addition to the gp130/IL6 pathway, enhanced RSUME in tumoral pituitary cells could be reached by other mechanisms, including hypoxia (Carbia-Nagashima et al. 2007) or heath shock (Druker $e$ t al. 2013), but also a regulatory positive feedback loop by PTTG.

All types of pituitary adenomas exhibit high PTTG levels (Saez et al. 1999, Musat et al. 2004). Increased RSUME levels in pituitary tumors has also been described (Carbia-Nagashima et al. 2007, Shan et al. 2012, Gerez et al. 2013, He et al. 2017). The interplay of these two proteins opens interesting future research avenues for further understanding of pituitary tumor pathogenesis.

In addition to pituitary tumors, PTTG was found to be overexpressed in many other tumors from different origins like thyroid (Lewy et al. 2012, Read et al. 2017), salivary gland (Liu et al. 2015), esophagus (Zhang et al. 2014), testis/ovary (Pei 1998, Panguluri et al. 2008), pancreatic islets, brain (Genkai et al. 2006, Salehi et al. 2013), breast (Solbach et al. 2004, Smith et al. 2010), prostate (Zhu et al. 2006), uterus (Tsai et al. 2005), lung/lymph/skin (McCabe \& Gittoes 1999) and others. This makes it interesting to deepen into the interaction PTTG/RSUME in other tumor tissues where PTTG is upregulated, and also the search for other factors that could be regulating the protein stabilization that leads to the abundance of tumoral PTTG.

\section{Declaration of interest}

The authors declare that there is no conflict of interest that could be perceived as prejudicing the impartiality of the research reported.

\section{Funding}

This work was supported by the Max Planck Society from Germany (grant number 2012/2016); University of Buenos Aires (UBA) from Argentina (grant numbers $\mathrm{N}^{\circ} 20020100100078, \mathrm{~N}^{\circ} 20020130100427 \mathrm{BA}$ ); the Consejo Nacional de Investigaciones Científicas y Técnicas (CONICET) from Argentina (D449 (01-03-2016)); the Agencia Nacional de Promoción Científica y Tecnológica (ANPCyT) from Argentina (grant numbers PICT2014-3634, PICT2016-1620); and Fondo para la Convergencia Estructural de Mercosur (FOCEM) (grant number COF 03/11). 


\section{Author contribution statement}

$\mathrm{E} \mathrm{A}$ and $\mathrm{M} \mathrm{F}$ conceived of and designed the experiments. M F, M S, L T, S S, A A and J J B carried out experiments. P A, G C, A C and G S collected biopsies and diagnosed subjects. M F, G K S and E A analyzed the data. $\mathrm{MF}$ and $\mathrm{E} A$ wrote the manuscript.

\section{Acknowledgments}

We thank L Poggio and G Gonzalez for technical assistance.

\section{References}

Amousha MR, Sabetkish NS, Heshmat R, Rajabiani A, Saffar H, Haghpanah V \& Tavangar SM 2015 Expression of the Pituitary Tumor Transforming Gene (PTTG1) in pheochromocytoma as a potential marker for distinguishing benign versus malignant tumors. Acta Medica Iranica 53 236-241.

Arzt E, Pereda MP, Castro CP, Pagotto U, Renner U \& Stalla GK 1999 Pathophysiological role of the cytokine network in the anterior pituitary gland. Frontiers in Neuroendocrinology 20 71-95. (https://doi. org/10.1006/frne.1998.0176)

Beckers A 2010 Higher prevalence of clinically relevant pituitary adenomas confirmed. Clinical Endocrinology 72 290-291. (https://doi. org/10.1111/j.1365-2265.2009.03726.x)

Boelaert K, McCabe CJ, Tannahill LA, Gittoes NJ, Holder RL, Watkinson JC, Bradwell AR, Sheppard MC \& Franklyn JA 2003 Pituitary tumor transforming gene and fibroblast growth factor-2 expression: potential prognostic indicators in differentiated thyroid cancer. Journal of Clinical Endocrinology and Metabolism $\mathbf{8 8}$ 2341-2347. (https://doi.org/10.1210/jc.2002-021113)

Boggio R, Colombo R, Hay RT, Draetta GF \& Chiocca S 2004 A mechanism for inhibiting the SUMO pathway. Molecular Cell 16 549-561. (https://doi.org/10.1016/j.molcel.2004.11.007)

Cancer Genome Research Network 2003 Comprehensive molecular characterization of clear cell renal cell carcinoma. Nature 499 43-49. (https://doi.org/10.1038/nature12222)

Carbia-Nagashima A, Gerez J, Perez-Castro C, Paez-Pereda M, Silberstein S, Stalla GK, Holsboer F \& Arzt E 2007 RSUME, a small RWD-containing protein, enhances SUMO conjugation and stabilizes HIF-1alpha during hypoxia. Cell 131 309-323. (https://doi. org/10.1016/j.cell.2007.07.044)

Castro CP, Giacomini D, Nagashima AC, Onofri C, Graciarena M, Kobayashi K, Paez-Pereda M, Renner U, Stalla GK \& Arzt E 2003 Reduced expression of the cytokine transducer gp130 inhibits hormone secretion, cell growth, and tumor development of pituitary lactosomatotrophic GH3 cells. Endocrinology 144 693-700. (https:// doi.org/10.1210/en.2002-220891)

Ciechanover A 1994 The ubiquitin-proteasome proteolytic pathway. Cell 79 13-21. (https://doi.org/10.1016/0092-8674(94)90396-4)

Clayton RN \& Farrell WE 2004 Pituitary tumour clonality revisited. Frontiers of Hormone Research 32 186-204.

Chesnokova V, Zonis S, Rubinek T, Yu R, Ben-Shlomo A, Kovacs K, Wawrowsky K \& Melmed S 2007 Senescence mediates pituitary hypoplasia and restrains pituitary tumor growth. Cancer Research $\mathbf{6 7}$ 10564-10572. (https://doi.org/10.1158/0008-5472.CAN-07-0974)

Chesnokova V, Zonis S, Kovacs K, Ben-Shlomo A, Wawrowsky K, Bannykh S \& Melmed S 2008 p21(Cip1) restrains pituitary tumor growth. PNAS 105 17498-17503. (https://doi.org/10.1073/ pnas.0804810105)

Dominguez A, Ramos-Morales F, Romero F, Rios RM, Dreyfus F, Tortolero M \& Pintor-Toro JA 1998 hpttg, a human homologue of rat pttg, is overexpressed in hematopoietic neoplasms. Evidence for a transcriptional activation function of hPTTG. Oncogene $\mathbf{1 7}$ 2187-2193. (https://doi.org/10.1038/sj.onc.1202140)

Drouin J, Bilodeau S \& Roussel-Gervais A 2010 Stem cells, differentiation and cell cycle control in pituitary. Frontiers of Hormone Research $\mathbf{3 8}$ $15-24$.

Druker J, Liberman AC, Antunica-Noguerol M, Gerez J, Paez-Pereda M, Rein T, Iniguez-Lluhi JA, Holsboer F \& Arzt E 2013 RSUME enhances glucocorticoid receptor SUMOylation and transcriptional activity. Molecular and Cellular Biology 33 2116-2127. (https://doi. org/10.1128/MCB.01470-12)

Dworakowska D \& Grossman AB 2012 The molecular pathogenesis of pituitary tumors: implications for clinical management. Minerva Endocrinologica 37 157-172.

Farrell WE 2014 Epigenetics of pituitary tumours: an update. Current Opinion in Endocrinology, Diabetes and Obesity 21 299-305. (https:// doi.org/10.1097/MED.0000000000000078)

Fernandez A, Karavitaki N \& Wass JA 2010 Prevalence of pituitary adenomas: a community-based, cross-sectional study in Banbury (Oxfordshire, UK). Clinical Endocrinology 72 377-382. (https://doi. org/10.1111/j.1365-2265.2009.03667.x)

Fowkes RC \& Vlotides G 2012 Hypoxia-induced VEGF production 'RSUMEs' in pituitary adenomas. Endocrine-Related Cancer 19 C1-C5. (https://doi.org/10.1530/ERC-11-0297)

Gao J, Aksoy BA, Dogrusoz U, Dresdner G, Gross B, Sumer SO, Sun Y, Jacobsen A, Sinha R, Larsson E, et al. 2013 Integrative analysis of complex cancer genomics and clinical profiles using the cBioPortal. Science Signaling 6 pl1.

Gatto F, Feelders R, van der Pas R, Kros JM, Dogan F, van Koetsveld PM, van der Lelij AJ, Neggers SJ, Minuto F, de Herder W, et al. 2013 betaArrestin 1 and 2 and G protein-coupled receptor kinase 2 expression in pituitary adenomas: role in the regulation of response to somatostatin analogue treatment in patients with acromegaly. Endocrinology 154 4715-4725. (https://doi.org/10.1210/en.2013-1672)

Geiss-Friedlander R \& Melchior F 2007 Concepts in sumoylation: a decade on. Nature Reviews Molecular Cell Biology 8 947-956. (https:// doi.org/10.1038/nrm2293)

Genkai N, Homma J, Sano M, Tanaka R \& Yamanaka R 2006 Increased expression of pituitary tumor-transforming gene (PTTG)- 1 is correlated with poor prognosis in glioma patients. Oncology Reports 15 1569-1574.

Gerez J, Fuertes M, Tedesco L, Silberstein S, Sevlever G, Paez-Pereda M, Holsboer F, Turjanski AG \& Arzt E 2013 In silico structural and functional characterization of the RSUME splice variants. PLOS ONE 8 e57795. (https://doi.org/10.1371/journal.pone.0057795)

Gerez J, Tedesco L, Bonfiglio JJ, Fuertes M, Barontini M, Silberstein S, Wu Y, Renner U, Paez-Pereda M, Holsboer F, et al. 2015 RSUME inhibits VHL and regulates its tumor suppressor function. Oncogene 34 4855-4866. (https://doi.org/10.1038/onc.2014.407)

Hay RT 2005 SUMO: a history of modification. Molecular Cell 18 1-12. (https://doi.org/10.1016/j.molcel.2005.03.012)

He W, Huang L, Shen X, Yang Y, Wang D \& Zhu X 2017 Relationship between RSUME and HIF-1alpha/VEGF-A with invasion of pituitary adenoma. Gene 603 54-60. (https://doi.org/10.1016/j. gene.2016.12.012)

Heaney AP, Horwitz GA, Wang Z, Singson R \& Melmed S 1999 Early involvement of estrogen-induced pituitary tumor transforming gene and fibroblast growth factor expression in prolactinoma pathogenesis. Nature Medicine 5 1317-1321. (https://doi. org/10.1038/15275)

Heaney AP, Singson R, McCabe CJ, Nelson V, Nakashima M \& Melmed S 2000 Expression of pituitary-tumour transforming gene in colorectal tumours. Lancet 355 716-719. (https://doi.org/10.1016/S01406736(99)10238-1)

Horwitz GA, Miklovsky I, Heaney AP, Ren SG \& Melmed S 2003 Human pituitary tumor-transforming gene (PTTG1) motif suppresses
(2) 2018 Society for Endocrinology Published by Bioscientifica Ltd. Printed in Great Britain 
prolactin expression. Molecular Endocrinology 17 600-609. (https:// doi.org/10.1210/me.2001-0006)

Huang CC, Tu SH, Lien HH, Jeng JY, Huang CS, Huang CJ, Lai LC \& Chuang EY 2013 Concurrent gene signatures for han chinese breast cancers. PLOS ONE 8 e76421. (https://doi.org/10.1371/journal. pone.0076421)

Huang S, Liu Q, Liao Q, Wu Q, Sun B, Yang Z, Hu X, Tan M \& Li L 2018 IL-6/STAT3 promotes prostate cancer resistance to androgen deprivation therapy via regulating PTTG1 expression. Cancer Science 109 678-687. (https://doi.org/10.1111/cas.13493)

Ito T, Shimada Y, Kan T, David S, Cheng Y, Mori Y, Agarwal R, Paun B, Jin Z, Olaru A, et al. 2008 Pituitary tumor-transforming 1 increases cell motility and promotes lymph node metastasis in esophageal squamous cell carcinoma. Cancer Research 68 3214-3224. (https:// doi.org/10.1158/0008-5472.CAN-07-3043)

Lewy GD, Sharma N, Seed RI, Smith VE, Boelaert K \& McCabe CJ 2012 The pituitary tumor transforming gene in thyroid cancer. Journal of Endocrinological Investigation 35 425-433.

Liu J, Wang Y, He H, Jin W \& Zheng R 2015 Overexpression of the pituitary tumor transforming gene upregulates metastasis in malignant neoplasms of the human salivary glands. Experimental and Therapeutic Medicine 10 763-768. (https://doi.org/10.3892/ etm.2015.2566)

Mastronardi L, Guiducci A, Buttaro FM, Cristallini EG, Puzzilli F \& Maira G 2001 Relationships among DNA index, S-phase, and invasive behavior in anterior pituitary adenomas. A cytometric study of 61 cases with Feulgen-positive DNA analysis. Surgical Neurology $\mathbf{5 6}$ 27-32. (https://doi.org/10.1016/S0090-3019(01)00455-4)

McCabe CJ \& Gittoes NJ 1999 PTTG - a new pituitary tumour transforming gene. Journal of Endocrinology 162 163-166. (https:// doi.org/10.1677/joe.0.1620163)

Melmed S 2011 Pathogenesis of pituitary tumors. Nature Reviews Endocrinology 7 257-266. (https://doi.org/10.1038/nrendo.2011.40)

Musat M, Vax VV, Borboli N, Gueorguiev M, Bonner S, Korbonits M \& Grossman AB 2004 Cell cycle dysregulation in pituitary oncogenesis. Frontiers of Hormone Research 32 34-62.

Ogbagabriel S, Fernando M, Waldman FM, Bose S \& Heaney AP 2005 Securin is overexpressed in breast cancer. Modern Pathology 18 985-990. (https://doi.org/10.1038/modpathol.3800382)

Paez-Pereda M, Giacomini D, Refojo D, Nagashima AC, Hopfner U, Grubler Y, Chervin A, Goldberg V, Goya R, Hentges ST, et al. 2003 Involvement of bone morphogenetic protein 4 (BMP-4) in pituitary prolactinoma pathogenesis through a Smad/estrogen receptor crosstalk. PNAS 100 1034-1039. (https://doi.org/10.1073/ pnas.0237312100)

Panguluri SK, Yeakel C \& Kakar SS 2008 PTTG: an important target gene for ovarian cancer therapy. Journal of Ovarian Research 1 6. (https:// doi.org/10.1186/1757-2215-1-6)

Pei L 1998 Genomic organization and identification of an enhancer element containing binding sites for multiple proteins in rat pituitary tumor-transforming gene. Journal of Biological Chemistry 273 5219-5225. (https://doi.org/10.1074/jbc.273.9.5219)

Pei L 1999 Pituitary tumor-transforming gene protein associates with ribosomal protein S10 and a novel human homologue of DnaJ in testicular cells. Journal of Biological Chemistry 274 3151-3158. (https://doi.org/10.1074/jbc.274.5.3151)

Pei L \& Melmed S 1997 Isolation and characterization of a pituitary tumor-transforming gene (PTTG). Molecular Endocrinology 11 433-441. (https://doi.org/10.1210/mend.11.4.9911)

Perez-Castro C, Renner U, Haedo MR, Stalla GK \& Arzt E 2012 Cellular and molecular specificity of pituitary gland physiology. Physiological Reviews 92 1-38. (https://doi.org/10.1152/ physrev.00003.2011)
Quereda V \& Malumbres M 2009 Cell cycle control of pituitary development and disease. Journal of Molecular Endocrinology 42 75-86. (https://doi.org/10.1677/JME-08-0146)

Ramos-Morales F, Dominguez A, Romero F, Luna R, Multon MC, PintorToro JA \& Tortolero M 2000 Cell cycle regulated expression and phosphorylation of hpttg proto-oncogene product. Oncogene 19 403-409. (https://doi.org/10.1038/sj.onc.1203320)

Read ML, Fong JC, Modasia B, Fletcher A, Imruetaicharoenchoke W, Thompson RJ, Nieto H, Reynolds JJ, Bacon A, Mallick U, et al. 2017 Elevated PTTG and PBF predicts poor patient outcome and modulates DNA damage response genes in thyroid cancer. Oncogene 36 5296-5308. (https://doi.org/10.1038/onc.2017.154)

Romero F, Multon MC, Ramos-Morales F, Dominguez A, Bernal JA, Pintor-Toro JA \& Tortolero M 2001 Human securin, hPTTG, is associated with $\mathrm{Ku}$ heterodimer, the regulatory subunit of the DNAdependent protein kinase. Nucleic Acids Research 29 1300-1307. (https://doi.org/10.1093/nar/29.6.1300)

Saez C, Japon MA, Ramos-Morales F, Romero F, Segura DI, Tortolero M \& Pintor-Toro JA 1999 hpttg is over-expressed in pituitary adenomas and other primary epithelial neoplasias. Oncogene 18 5473-5476. (https://doi.org/10.1038/sj.onc.1202914)

Salehi F, Scheithauer BW, Sharma S, Kovacs K, Lloyd RV, Cusimano MD \& Munoz DG 2013 Immunohistochemical expression of PTTG in brain tumors. Anticancer Research 33 119-122.

Sapochnik M, Haedo MR, Fuertes M, Ajler P, Carrizo G, Cervio A Sevlever G, Stalla GK \& Arzt E 2017 Autocrine IL-6 mediates pituitary tumor senescence. Oncotarget 8 4690-4702.

Schneider BP, Li L, Radovich M, Shen F, Miller KD, Flockhart DA, Jiang G, Vance G, Gardner L, Vatta M, et al. 2015 Genome-wide association studies for taxane-induced peripheral neuropathy in ECOG-5103 and ECOG-1199. Clinical Cancer Research 21 5082-5091. (https://doi.org/10.1158/1078-0432.CCR-15-0586)

Shan B, Gerez J, Haedo M, Fuertes M, Theodoropoulou M, Buchfelder M, Losa M, Stalla GK, Arzt E \& Renner U 2012 RSUME is implicated in HIF-1-induced VEGF-A production in pituitary tumour cells. Endocrine-Related Cancer 19 13-27. (https://doi.org/10.1530/ERC-110211)

Smith VE, Franklyn JA \& McCabe CJ 2010 Pituitary tumor-transforming gene and its binding factor in endocrine cancer. Expert Reviews in Molecular Medicine 12 e38. (https://doi.org/10.1017/ S1462399410001699)

Solbach C, Roller M, Fellbaum C, Nicoletti M \& Kaufmann M 2004 PTTG mRNA expression in primary breast cancer: a prognostic marker for lymph node invasion and tumor recurrence. Breast $\mathbf{1 3}$ 80-81. (https://doi.org/10.1016/j.breast.2003.09.008)

Tong Y \& Eigler T 2009 Transcriptional targets for pituitary tumortransforming gene-1. Journal of Molecular Endocrinology 43 179-185. (https://doi.org/10.1677/JME-08-0176)

Tong Y, Tan Y, Zhou C \& Melmed S 2007 Pituitary tumor transforming gene interacts with Sp1 to modulate G1/S cell phase transition. Oncogene 26 5596-5605. (https://doi.org/10.1038/sj.onc.1210339)

Tong Y, Ben-Shlomo A, Zhou C, Wawrowsky K \& Melmed S 2008 Pituitary tumor transforming gene 1 regulates Aurora kinase A activity. Oncogene 27 6385-6395. (https://doi.org/10.1038/ onc.2008.234)

Tsai SJ, Lin SJ, Cheng YM, Chen HM \& Wing LY 2005 Expression and functional analysis of pituitary tumor transforming gene-1 (corrected) in uterine leiomyomas. Journal of Clinical Endocrinology and Metabolism 90 3715-3723. (https://doi.org/10.1210/jc.20042303)

Uccella S, Tibiletti MG, Bernasconi B, Finzi G, Oldrini R \& Capella C 2005 Aneuploidy, centrosome alteration and securin overexpression as features of pituitary somatotroph and lactotroph
2018 Society for Endocrinology Published by Bioscientifica Ltd. Printed in Great Britain 
adenomas. Analytical and Quantitative Cytology and Histology $\mathbf{2 7}$ 241-252.

Wang Z, Yu R \& Melmed S 2001 Mice lacking pituitary tumor transforming gene show testicular and splenic hypoplasia, thymic hyperplasia, thrombocytopenia, aberrant cell cycle progression, and premature centromere division. Molecular Endocrinology 15 1870-1879. (https://doi.org/10.1210/mend.15.11.0729)

Wang Z, Moro E, Kovacs K, Yu R \& Melmed S 2003 Pituitary tumor transforming gene-null male mice exhibit impaired pancreatic beta cell proliferation and diabetes. PNAS 100 3428-3432. (https://doi. org/10.1073/pnas.0638052100)

Yu R, Lu W, Chen J, McCabe CJ \& Melmed S 2003 Overexpressed pituitary tumor-transforming gene causes aneuploidy in live human cells. Endocrinology 144 4991-4998. (https://doi.org/10.1210/en.20030305)

Zhang X, Horwitz GA, Heaney AP, Nakashima M, Prezant TR, Bronstein MD \& Melmed S 1999a Pituitary tumor transforming gene (PTTG) expression in pituitary adenomas. Journal of Clinical Endocrinology and Metabolism 84 761-767. (https://doi.org/10.1210/ jcem.84.2.5432)
Zhang X, Horwitz GA, Prezant TR, Valentini A, Nakashima M, Bronstein MD \& Melmed S 1999b Structure, expression, and function of human pituitary tumor-transforming gene (PTTG). Molecular Endocrinology 13 156-166. (https://doi.org/10.1210/ mend.13.1.0225)

Zhang J, Yang Y, Chen L, Zheng D \& Ma J 2014 Overexpression of pituitary tumor transforming gene (PTTG) is associated with tumor progression and poor prognosis in patients with esophageal squamous cell carcinoma. Acta Histochemica 116 435-439. (https:// doi.org/10.1016/j.acthis.2013.09.011)

Zhou C, Tong Y, Wawrowsky K \& Melmed S 2014 PTTG acts as a STAT3 target gene for colorectal cancer cell growth and motility. Oncogene 33 851-861. (https://doi.org/10.1038/onc.2013.16)

Zhu X, Mao Z, Na Y, Guo Y, Wang X \& Xin D 2006 Significance of pituitary tumor transforming gene 1 (PTTG1) in prostate cancer. Anticancer Research 26 1253-1259.

Zou H, McGarry TJ, Bernal T \& Kirschner MW 1999 Identification of a vertebrate sister-chromatid separation inhibitor involved in transformation and tumorigenesis. Science 285 418-422. (https://doi. org/10.1126/science.285.5426.418)

Received in final form 15 March 2018

Accepted 5 April 2018

Accepted Preprint published online 5 April 2018
(C) 2018 Society for Endocrinology Published by Bioscientifica Ltd. Printed in Great Britain 